\title{
Conifer Dispersion on Subalpine Pastures in Northeastern Spain: Characteristics and Implications for Rangeland Management
}

\author{
Jordi Bartolomé, Martí Boada, ${ }^{2}$ David Saurí, ${ }^{3}$ Sònia Sánchez, ${ }^{4}$ and Josefina Plaixats ${ }^{1}$ \\ Authors are ${ }^{1}$ Associate Professors, Departament de Ciència Animal i dels Aliments, Grup de Recerca en Remugants, Universitat Autònoma de Barcelona, \\ 08193 Bellaterra, Spain; ${ }^{2}$ Associate Professor, Institut de Ciència i Tecnologia Ambientals, Universitat Autònoma de Barcelona, 08193 Bellaterra, Spain; \\ ${ }^{3}$ Professor, Departament de Geografia, Universitat Autònoma de Barcelona, 08193 Bellaterra, Spain; and ${ }^{4}$ PhD student, Institut de Ciència i Tecnologia \\ Ambientals, Universitat Autònoma de Barcelona, 08193 Bellaterra, Spain.
}

\begin{abstract}
Pinus sylvestris L. and Pinus mugo Turra originating from two plantations established during the 1960s are invading subalpine heathlands higher than $1500 \mathrm{~m}$ above sea level in Montseny Natural Park (northeast Spain). Both species are native at a regional scale but may not have been present in the park's subalpine vegetation previously. In addition, Abies alba P. Mill., which is in regression in many areas in Europe, is also colonizing the area from a neighboring natural forest. This invasion appears to be stimulated by a combination of natural and human factors, including differences between vegetation components, climate (i.e., drought periods), changes in land use due to conservation policies (i.e., suppressing fire or grazing practices), the creation of the plantations, and probably the nurse role played by accompanying dwarf shrubs (Calluna vulgaris [L.] Hull and Juniperus communis subsp. nana [Willd.] Syme). We examined the effects of this process in terms of the spatial dispersion and characteristics of the established conifers and deduce implications for the conservation of isolated subalpine pastures in Mediterranean Basin mountains. P. sylvestris was the most successful invading species in this area. The P. mugo invasion is distributed mainly near the plantation. The only native conifer species, A. alba, appears to be colonizing only the eastern slope. The invasion process is related to the diversity and species richness recorded on each slope. Conserving valuable subalpine heathlands at the latitude of the Montseny mountain range implies suppressing propagule pressures from the plantations. The option of removing conifers that are nonnative, at a local scale, must be considered. However, in the case of the native A. alba this option leads to a management conflict between conserving former pastureland and the dispersion of A. alba.
\end{abstract}

\section{Resumen}

Las especies Pinus sylvestris L. y Pinus mugo Turra, procedentes de dos plantaciones establecidas durante la decada 1960-1970, están invadiendo los páramos subalpinos superiores a los $1500 \mathrm{~m}$ sobre el nivel del mar (snm) en el Parque Natural del Montseny (NE España). Ambas especies son nativas a escalas regionales, pero puede que no hayan estado presentes en la vegetación subalpina del Parque con anterioridad. Además, la especie Abies alba P. Mill., que se encuentra en regresión en muchas zonas de Europa, también está colonizando la zona desde un bosque natural colindante. Esta invasión parece ser estimulada por una combinación de factores naturales y humanos, incluyendo diferencias entre componentes vegetacionales, clima (p.e. períodos de sequía), cambios en el uso de la tierra debido a las políticas de conservación (p.e. supresión de fuegos o prácticas de pastoreo), creación de plantaciones y probablemente el papel nodriza desempeñado por los arbustos enanos (Calluna vulgaris [L.] Hull y de Juniperus communis subsp. nana [Willd.] Syme). Hemos examinado los efectos de este proceso en términos de la dispersión espacial y las características de las coníferas establecidas y deducimos las implicaciones para la conservación de los pastizales subalpinos aislados en las montañas del Mediterráneo. P. sylvestris fue la especie invasora más éxitosa en este área. La invasión de $P$. mugo se distribuye principalmente cerca de la plantación. La única especie nativa de coníferas, A. alba, parece està colonizando sólo la pendiente este. El proceso de invasión está relacionado con la diversidad y con la riqueza de especies encontradas en cada pendiente. La conservación de valiosos páramos subalpinos en la latitud de la sierra del Montseny implica suprimir las presiones de los propágulos de las plantaciones. La opción de eliminar las coníferas que no son nativas, a escalas locales, debe ser considerada. Sin embargo, en el caso de la nativa A. alba esta opción conduce a un conflicto de manejo entre la conservación de antiguos pastizales y la dispersión de A. alba.

Key Words: Abies, colonization, land use, Mediterranean mountains, Pinus, plantation

\section{INTRODUCTION}

Invasions can be considered as one negative aspect of global environmental change because they may represent a serious threat to conserving the host ecosystems (Lodge 1993; Groves and Di Castri 1991; Pimentel 2002; Wolf et al. 2003). In

Correspondence: Dr Jordi Bartolomé Filella, Departament de Ciència Animal i dels Aliments Universitat Autònoma de Barcelona, Bellaterra 08193, Spain. Email: jordi.bartolome@uab.es

Manuscript received 30 May 2007; manuscript accepted 29 November 2007. particular, invading conifer species have become dominant in many parts of the world and have experienced rapid increases during the last 100 years producing significant environmental impacts, even leading to species extinction on the affected lands (Richardson et al. 1994; Richardson 1998).

In terms of land use changes, successful conifer invasions, particularly of pines, have been widely reported (e.g., Richardson and Bond 1991; Richardson and Higgins 1998). In the Pyrenees, pines occupy former Fagus sylvatica L. forests cut for timber and exposed to erosion (Villar et al. 1993). 
Historical records of management abandonment practices, including burning and grazing, show succession leading to conifer dominance in previous deciduous forests in Sweden (Bradshaw and Hannon 1992), Maryland oak savannas and grasslands (Tyndall 1992), and the United States (Waldrop et al. 1992; Mast et al. 1997).

The family Pinaceae displays great variability in its ability to invade. It is considered equally or more invasive than any predominant woody member of the angiosperm family (Richardson and Rejmanek 2004). Pine seeds from plantations are able to disperse into adjoining natural or seminatural habitats to initiate large-scale invasions. These invasions contribute to an overall reduction in native biodiversity in many of the areas affected (Richardson 1998; Bustamante and Simonetti 2005).

Despite the fact that the distribution and abundance of some Mediterranean pine species can be explained mainly by abiotic factors such as elevation and rainfall variability (Rouget et al. 2001), the factors explaining why pines become invasive seem to be diverse and have been the objective of many contributions to the literature over the last few decades. Among the important determinants are their greater tolerance to stressed environments (Keeley and Zedler 1998) and climate constraints (Dodson and Bradshaw 1987). However, human factors have also had a major influence on the Mediterranean Basin since prehistoric times (Barbero et al. 1998). Reforestation programs with regional native species have promoted a "natural diffusion" from plantations into other communities (Willis et al. 1998). The most extensive summary of the major factors that determine the invasion process of pines from planting sites was given by Higgins and Richardson (1998). They concluded that the rate of invasion is increased by greater levels of disturbance and that grasslands and shrublands can be invaded more easily than forests.

The ecological characteristics of the invaded land, particularly vegetation structure and composition, can play an important role in facilitating or constraining invasions. One example is the role of other, more pioneering species such as shrubs that perform nurse plant functions (Drezner and Garrity 2003). This is the case of Juniperus communis (Rousset and Lepart 1999). These shrubs can promote the survival and growth of pine seedings (Gómez Aparicio et al. 2004).

The objective of this paper is to describe and quantify the expansion of conifers into isolated heathlands after the establishment of regulations concerning traditional management. More specifically, it examines the spatial extension and characteristics of conifer dispersion in subalpine heath pastures located in the highest areas of the Montseny mountain range of northeast Spain. Further, the paper explores various causes that may influence the colonizing process, including slope orientation, vegetation components, land use practices, climate change, and the role of nurse plants. In addition, it addresses the implications of this invasion for the conservation of a scarce and, by virtue of its extreme meridionality, rare mountain ecosystem in the Mediterranean Basin.

\section{MATERIALS AND METHODS}

\section{Study Area}

The Montseny mountain range (1 $707 \mathrm{~m}$ above sea level [a.s.l.]) is located in the northeastern part of the Iberian peninsula, in the Mediterranean region. The climate at the highest point, however, is temperate with an average annual temperature of $7^{\circ} \mathrm{C}$ and an average annual precipitation of $1000 \mathrm{~mm}$. Fortynine percent of annual windy days are westerly, closely followed by easterly winds $(40 \%)$. Broadly speaking, the Montseny area presents three ecosystems organized according to altitude. Mediterranean vegetation, especially holm oak (Quercus ilex L.) and its accompanying species, dominates the lower slopes of the mountain (up to $900 \mathrm{~m}$ ). Euro-Siberian vegetation, with beech (Fagus sylvatica) and patches of fir (Abies alba) forests, extends from 900 to $1600 \mathrm{~m}$, although its distribution varies, depending on orientation and exposure. Finally, subalpine dwarf shrub heathlands with heather (Calluna vulgaris), bilberry (Vaccinum myrtilus L.), dwarf juniper (Juniperus communis subsp. nana), and intermixed grasslands are present above $1600 \mathrm{~m}$. The Montseny mountain range hosts one of the most southern ecotonic distributions of beech and Atlantic heathlands in Europe. Beech and holm oak forests appear to be moving upwards since the 1940s, replacing heathlands and grasslands, probably because of climate change (Peñuelas and Boada 2003). In addition, changes in land use, such as cultivation followed by abandonment, as well as fire protection, have been recorded as important causes of the loss of heathland in the park (Bartolomé et al. 2004).

The study area included the 82 ha of subalpine vegetation located around the Turó de l'Home peak (1707 m a.s.l.) distributed between three main slope orientations. Table 1 shows the characteristics of each study slope and densities of conifer invaders. This area is traditionally grazed during late spring and summer (Llobet 1947) by livestock composed of two herds of sheep (600 and 350 animals, respectively) and one herd of cows (30 animals). Stocking densities were appropriate to the United Kingdom's recommendations for heathlands with very poor quality forage where grazing is restricted to the summer months (Williams 2003). These pastures are dominated by heather (C. vulgaris), intermixed with dry grasslands on the crests (less than $10 \%$ of pastureland surface) and dwarf juniper (J. communis nana) on the north and east slopes. There is a clear example of C. vulgaris-J. communis nana heath according to British National Vegetation Classification (Rodwell 1991) on the northern face. This community is rare in the Mediterranean region. Shepherds used to burn scattered shrubs (juniper and heather) until the Montseny area was declared a Natural Park in 1977 and a Biosphere Reserve in 1978 and the use of fire was banned.

Two regional native species of conifers, Scots pine $(P$. sylvestris) and Mountain pine ( $P$. mugo), have appeared in recent years as successful invaders of the area. Two-year-old seedlings of both species provided by a forestry nursery $800 \mathrm{~km}$ away (the Spanish region of Castilla and Léon) were planted on the highest reaches of the mountain in the 1960s. P. sylvestris was planted between 1100 and $1500 \mathrm{~m}$ a.s.l. on former agricultural terraces on the southern slopes, situated between 0.5 and $1 \mathrm{~km}$ from the subalpine heathland border. Currently the nearest natural population of $P$. sylvestris is located in the holm oak forest domain, below $1000 \mathrm{~m}$ a.s.l. and $8 \mathrm{~km}$ away. P. mugo was planted at $1600 \mathrm{~m}$ a.s.l. in the heathland pastures in the so-called Plana Amagada enclave on the southern slope of the subalpine area. The nearest existing natural population is $70 \mathrm{~km}$ to the north in the Pyrenees Mountains. Neither 
Table 1. Surfaces of each study slope, number of individual invaders, and density around the Turó de l'Home peak (Montseny Natural Park, 2000).

\begin{tabular}{lcccc}
\hline & \multicolumn{3}{c}{ Slope orientation } & \\
\cline { 2 - 4 } & $\mathrm{N}(\mathrm{NE})$ & $\mathrm{E}$ & $\mathrm{S}(\mathrm{SW})$ & Total \\
\hline Surface (ha) & 35.50 & 12.12 & 34.80 & 82.42 \\
Conifer individuals & & & & \\
$\quad$ Abies alba & 1 & 36 & 3 & 40 \\
$\quad$ Pinus mugo & 2 & 0 & 86 & 88 \\
$\quad$ Pinus sy/vestris & 31 & 57 & 33 & 121 \\
$\quad$ Indeterminate & 1 & 1 & 14 & 16 \\
$\quad$ Total $\left._{\text {Density (individuals.ha }}{ }^{-1}\right)$ & 35 & 94 & 136 & 265 \\
\hline
\end{tabular}

${ }^{1}$ Hybrid individuals (P. sylvestris $\times$ P. mugo).

species has been previously recorded in subalpine heathlands of Montseny. Nevertheless, the plantations constitute important foci of propagule emission for this species. The formation of a carpet of pine needles and the well-documented impact of pine plantations on water flows (e.g., Rutter 1967; Bubb and Croton 2002) partly discourages the regeneration of native floor species. The lack of an herbaceous stratum in the understory of these plantations implies a reduction of forage availability and suggests that conifer expansion could transform the former pastures if the tree density increases over the next decades. In addition, A. alba is also spreading in the heathland, although it has a natural population next to the area on the northern slope, between 1200 to $1500 \mathrm{~m}$ a.s.l., and located less than $0.5 \mathrm{~km}$ from the heathland border. It has never been planted.

\section{Field Measurements}

For each of the three slopes (outside the plantations and natural forest areas) we recorded each individual established sapling (Fig. 1) and its characteristics: species, height, diameter at breast height $(\mathrm{DBH})$, distance from the original plantation, approximate age (annual growth estimated from branch knots), habitat, and accompanying species.

An exploration of the accompanying species on the three slopes was performed using a $2-\mathrm{m}$ radius circumference surrounding each tree. Species covering more than $75 \%$ of this area were recorded as the "main accompanying species." When dwarf juniper (J. communis nana) and heather (C. vulgaris) were the main accompanying species, the biggest stem was cut to determine their age by counting the tree rings.

Distribution of the heathland species on each slope was determined in late spring by measuring the abundance of all species along 18 line point transects (6 randomly replicated transects on each slope), each $10 \mathrm{~m}$ long. All species encountered by a vertical needle, placed every $10 \mathrm{~cm}$, were recorded along the line point transects. Canopy cover of dwarf shrubs was also determined by measuring the segments intercepted along two 100-m line transects on each slope. The height of each individual shrub intercepted was also recorded. Fieldwork took place in the spring and summer of 2000.

\section{Data Analysis}

To analyze the importance of vegetation in the conifer establishment process, we analyzed the relationship between vegetation components, such as J. communis nana, C. vulgaris, graminoids, nongraminoids, and bare ground abundance, and slope orientation using an analysis of variance (one-way analysis of variance) with SPSS software. We determined differences using the HSD Tukey test. Using the Pearson correlation test, we analyzed the relationships within the same vegetation components. To characterize species diversity in each heathland type (according to their orientation), we calculated the Shannon-Wiener diversity index. Mean values are followed by standard deviation $( \pm \mathrm{SD})$.
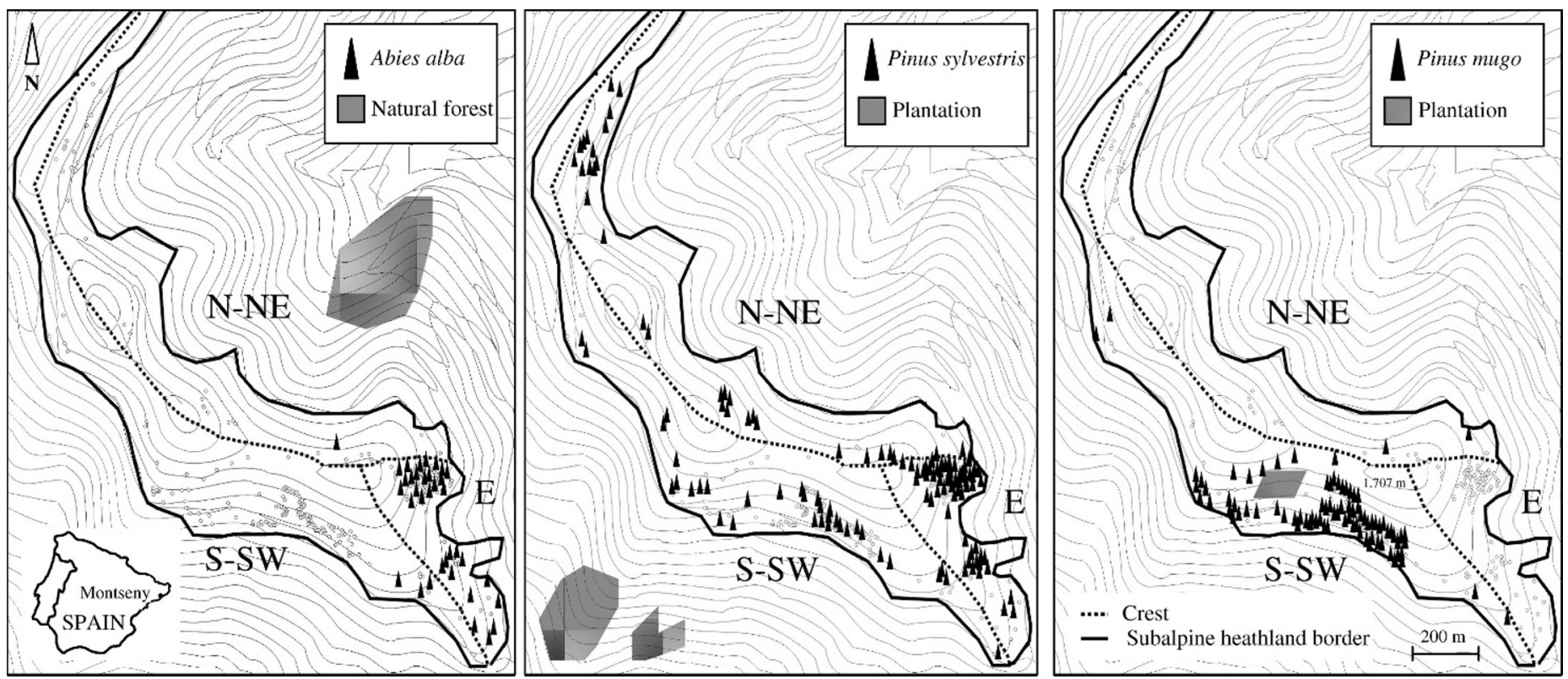

Figure 1. Spatial distribution of the conifer invaders in the subalpine pastures in Montseny Natural Park. 

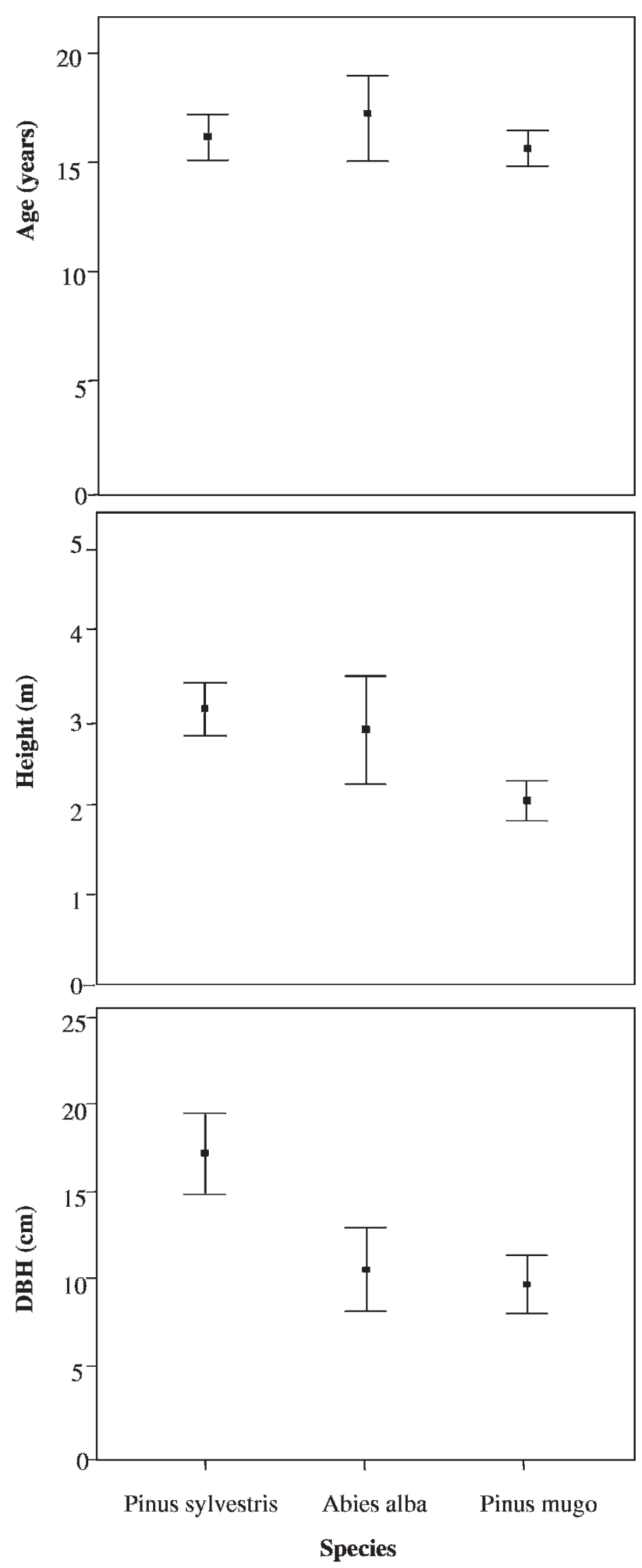

Figure 2. Mean values of structural parameters for each conifer species. Bars indicate SD.

\section{RESULTS}

\section{Characteristics of Conifer Invaders}

The largest numbers of invading trees (164 individuals or about $61 \%$ of the total) germinated between 1983 and 1986. Mean age values are effectively equal in the three species (Fig. 2). This means that the heathland invasion process of both Pinus species started when pine plantations reached maturity, more or less when protection measures were established (i.e., fire prohibition). A. alba also started its colonization process around this time.

This was the driest and warmest period of the last decades on the Turó de l'Home peak. Temperatures in 1983 and 1984 registered $1-1.7^{\circ} \mathrm{C}$ more than the mean annual temperature (8.0 and $8.7^{\circ} \mathrm{C}$, respectively), while only $700 \mathrm{~mm}$ of precipitation occurred in 1985 . The respective temperatures and precipitation values are the highest and the lowest recorded since 1945 (Boada 2001).

During the same period dwarf shrubs J. communis nana and C. vulgaris surrounding conifer individuals were 19-22 and 58 years old, respectively (calculated from data recorded in 2000, when they showed a mean age of $36 \pm 5.5$ and $22 \pm 2.4$ years, respectively). Currently both shrubs encircle the bases of 172 individuals, or $65 \%$ of all conifer invaders recorded (Fig. 3).

Most individuals are shorter than $3.2 \mathrm{~m}$ (Fig. 2). The tallest individuals are $P$. sylvestris followed by $A$. alba. At a certain height some individuals of $P$. sylvestris present some limitations because they are affected by breaks in their apical zone, probably caused by accumulated snow to which this species is very vulnerable. $P$. sylvestris had the highest mean $\mathrm{DBH}$ value, and $A$. alba and P. mugo had very similar values.

As expected, there was a significant positive correlation between the three factors studied: age, height, and DBH (Pearson correlation, $P<0.01)$. It indicates a common growing trait and the potential to become a mature conifer invader population.

\section{Distribution of Conifer Invaders}

In the understory of the plantations the recruitment level is virtually nonexistent, although there is a colonizing dispersion toward neighboring land covers, especially toward subalpine heathlands (Fig. 1). The mean distance of $P$. sylvestris saplings from the border of the parent plantation area is $830 \mathrm{~m}$, with a maximum of $1920 \mathrm{~m}$; P. mugo saplings are only $190 \mathrm{~m}$ from the parent plantation, with a maximum of $680 \mathrm{~m}$, and $A$. alba saplings are $480 \mathrm{~m}$ from the border of the natural fir forest, with a maximum of $910 \mathrm{~m}$. Currently the canopy cover of all conifer invaders/ colonizers has been estimated to be $1.2 \%$ of the former grazed area.

$P$. sylvestris must be considered the most successful colonizing species in this area. There are large numbers of individuals, and it is well represented on the three faces of the peak (Table 1). It is followed by $P$. mugo, whose invasion area is distributed mainly on the southern face, not far from the plantation (Fig. 1). A. alba is a local conifer, colonizing heathlands from a neighboring natural population. Its expansion is restricted to the eastern face.

On the northern face we registered a density of only one individual per hectare. On this site the most invasive species is $P$. sylvestris, the species with the greatest capacity for lineal propagation (Fig. 1). In this case it seems important to note that the canopy cover of the dominant shrub J. communis nana 


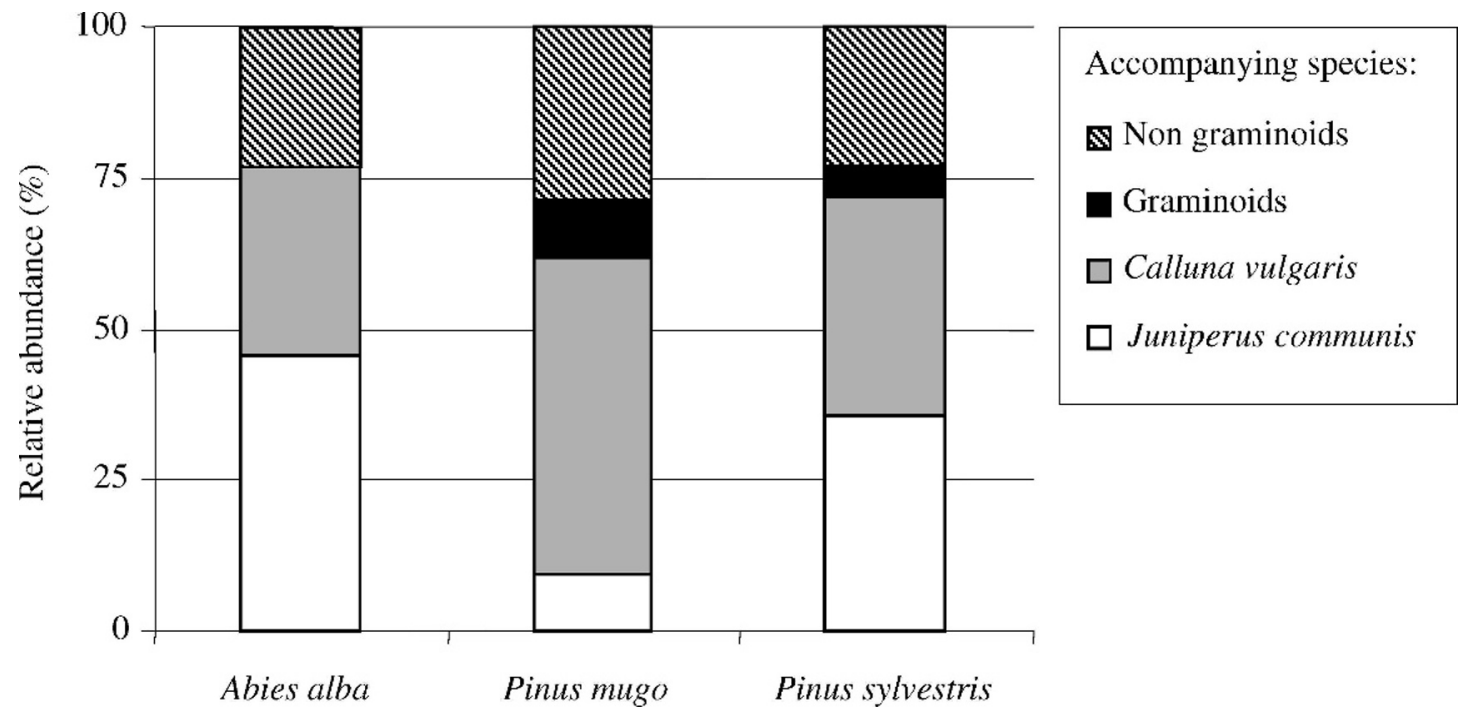

Figure 3. Relative abundance of the main accompanying species for each conifer species.

is very high, covering $72 \pm 14.7 \%$ of the area and averaging $50 \pm 14.1 \mathrm{~cm}$ high.

The highest tree density was found on the eastern slope with almost eight individuals per hectare. A. alba species were the most successful colonizer in this section. Here the canopy cover of the dominant shrub C. vulgaris is almost as high, covering $54 \pm 0.8 \%$ of the slope but with a lower height value, $17 \pm 2.4 \mathrm{~cm}$. In addition, $75 \%$ of the main individuals accompanying $A$. alba are C. vulgaris and J. communis nana (Fig. 3). However, this slope showed the lowest values for graminoid abundance (Table 2 ), therefore reducing the possible control of conifer establishment played by these species in terms of competition for resources.

On the southern face, density is four individuals per hectare. Here the dominant species is $P$. mugo due to the existing plantation in the nearby area of Plana Amagada. This dominance is shared with $P$. sylvestris. On this slope the herbaceous component is the most prominent. Shrubs are scattered and have the lowest abundance values (Table 3).

\section{DISCUSSION}

In Montseny Natural Park, conifer plantations established during the 1960s have expanded into heathland pastures by

Table 2. Vegetation features of the study area in Montseny Natural Park in 2000. ${ }^{1}$

\begin{tabular}{lccc}
\hline \multicolumn{1}{c}{ Slope orientation } & N (NE) & $\mathrm{E}$ & $\mathrm{S}(\mathrm{SW})$ \\
\hline Species richness $(n)$ & $23 \mathrm{a}$ & $13 \mathrm{c}$ & $21 \mathrm{~b}$ \\
Diversity (Shannon index) & $3.24 \mathrm{a}$ & $2.40 \mathrm{~b}$ & $2.96 \mathrm{a}, \mathrm{b}$ \\
Relative abundance (\%) & & & \\
$\quad$ Juniperus communis & $25.95 \mathrm{a}$ & $14.15 \mathrm{~b}$ & $0.1 \mathrm{c}$ \\
Calluna vulgaris & $8.46 \mathrm{~b}$ & $42.65 \mathrm{a}$ & $7.96 \mathrm{~b}$ \\
Graminoids & $39.98 \mathrm{a}$ & $33.27 \mathrm{~b}$ & $52.42 \mathrm{a}$ \\
Nongraminoids & $25.50 \mathrm{a}$ & $8.46 \mathrm{~b}$ & $34.17 \mathrm{a}$ \\
Bare ground & 0.11 & 1.47 & 5.46 \\
\hline
\end{tabular}

${ }^{1}$ Means in the same row with different letters are significantly different $(P<0.05)$. recruitment of young individuals of $P$. sylvestris (46\%) and $P$. mugo $(33 \%)$. This process could have been stimulated by a period of warm and dry climate conditions and facilitated by the presence of nurse shrubs. This expansion has been observed only in the Turó de l'Home peak and not in the neighboring Matagalls Peak (1,697 m a.s.l.) where plantations are absent. Hence, it suggests that plantations constitute the most important source of propagules.

According to Colautti and MacIsaac (2004) "nativeness" on a spatial scale must be defined by separating long-distance transport vectors, which are unique to nonindigenous species, from those responsible for local spread. In this work we considered both species of Pinus as nonindigenous at the local scale, even though they are well distributed in the northeast of Spain (Rouget et al. 2001) and A. alba is an indigenous species. To use appropriate terminology in the invasion ecology field we followed the work by Richardson (1998). Richardson considers "invaders" to be all trees planted in alien environments that frequently recruit seedlings, often in very large numbers, in natural or seminatural vegetation at distances of more than $100 \mathrm{~m}$ from parent plants. In our case the word can be applied to both Pinus species but not to A. alba, which is spreading from a natural population.

Results from previous work (e.g., Hunter and Douglas 1984; Richardson et al. 1994) confirm the prolific nature of both

Table 3. Relationship between the abundance of each vegetation component, species richness, and diversity of subalpine heathlands in Montseny Natural Park. Data shown correspond to the $r$ values of the Pearson correlation test.

\begin{tabular}{lccccc}
\hline & $\begin{array}{c}\text { Calluna } \\
\text { vulgaris }\end{array}$ & Graminoids & Nongraminoids & $\begin{array}{c}\text { Species } \\
\text { richness }\end{array}$ & $\begin{array}{c}\text { Shannon } \\
\text { index }\end{array}$ \\
\hline Juniperus & -0.128 & 0.268 & 0.217 & $0.565^{*}$ & $0.551^{*}$ \\
$\quad$ communis & & & & & \\
Calluna vulgaris & $-0.559^{*}$ & $-0.724^{* *}$ & $-0.543^{*}$ & -0.440 \\
Graminoids & & & $0.795^{* *}$ & $0.684^{* *}$ & $0.723^{* *}$ \\
Nongraminoids & & & $0.836^{* *}$ & $0.794^{* *}$ \\
Species richness & & & & $0.884^{* *}$ \\
$* P<0.05^{* *} P<0.01$ & & & &
\end{tabular}


Pinus species and their rapid growth, especially in pasturelands. The expansion of both pines in this area demonstrates that these species have the potential to become invasive and perform as well as, or better than, the native conifer species A. alba. The invasion process started when planted pine seedlings reached maturity and protection measures were established in the 1980s. A similar phenomenon of invasion originating from conifer plantations appears repeatedly in the scientific literature (e.g., Richardson and Higgins 1998; Kilgore and Telewski 2004). In addition, Kuiters (2002) in the Netherlands found that the cessation of turf cutting and controlled fire management of heathlands resulted in a rapid outbreak of trees growing in the area, especially $P$. sylvestris.

The livestock stocking rate of the area may influence the invasion process of $P$. sylvestris and $P$. mugo. It is known that herbivores can facilitate the invasion by removing competing vegetation or by dispersing pine seeds (Richardson and Bond 1991) but can also check the process by browsing on seedlings. Moreover, its relative resistance to animal grazing may also explain the success of $P$. sylvestris (Palmer and Truscott 2003). In the same way the intolerance of $P$. mugo to shade favors its expansion by grazing animals clearing the land (Kienast et al. 1999).

The invasion process could also be related to the warming trend experienced in the area during the last 50 years, with a mean increase of $1.2^{\circ} \mathrm{C}$ at the Turó de l'Home peak between 1940 and 1995 (Boada 2001). This increase in temperature has been considered to be associated with ameliorating growing conditions near the alpine timberline (Rolland et al. 1998), contributing to an increase in the range distribution of the conifer species. The confluence of a warm and dry period, such as that of 1983-1985, with maturing plantations and land use changes associated with conservation measures probably resulted in the main germination event of these species. This could explain why all of the conifer species belong to a similar age cohort.

As far as we know, A. alba has scarcely been cited as a naturalized species (Richardson and Rejmanek 2004) and never as invasive of pasturelands in the literature. Rather, it is considered to be in decline in Europe (Bert 1993; Leban et al. 1998; Camarero et al. 2002). According to Senn and Suter (2003), many authors refer to A. alba as the conifer most sensitive to grazing by wild ungulates. Therefore, these animals would be largely responsible for its regulation. However, for these authors A. alba populations also depend on other factors becoming highly variable both in time and in space. In our study area the relative success of these firs $(15 \%$ of conifer colonizers) is restricted to the eastern slope, and it could depend on the interaction of several factors: lack of large wild ungulates (especially in wintertime), slope characteristics, former vegetation, and the nursing effect of both the scattered dwarf junipers (J. communis nana) and abundant heather ( $C$. vulgaris). The last is supported by the high amount of saplings $(77 \%)$ that today are still accompanied by these shrubs (Fig. 3).

The highest density of conifer colonizers occurs on the eastern slope. Taking into account that the main dispersal strategy of these conifer species is anemochorous, it is possible that the predominance of westerly winds could contribute to this distribution. The vegetation diversity value on this slope is the lowest. The dominance of C. vulgaris has probably played an important role in facilitating the process of conifer colonization by reducing competition between saplings and herbaceous species (Van Auken and Bush 1990; Casper and Jackson 1997). Its moderate height and canopy cover protects conifer propagules from direct sunlight (Diaci 2002), creating favorable conditions for A. alba, which is considered a more shade-tolerant conifer species (Rolland et al. 1999). This hypothesis is supported by the negative correlation between the abundance of $C$. vulgaris and the abundance of herbaceous components (graminoids and nongraminoids) and species richness that decreased when C. vulgaris increased (Table 3). Moreover, C. vulgaris is an important component of the livestock's diet in the pastures of Montseny Natural Park (Bartolomé et al. 1998), suggesting that the animals prefer to graze on this species and avoid conifers, reducing their possible control.

The opposite occurs on the northern slope, where the invader density has its lowest value and vegetation diversity is at its highest. This could be related to the former community of $C$. vulgaris-J. communis nana heath, which was described in botanical studies of the area in the early 1940s (Bolòs 1983). Its higher diversity and species richness values (Table 2) mean that this community is, in ecological terms, more stationary than the southern and eastern heathlands. In this case the dominance and high canopy cover of J. communis nana could have played an inverse role to C. vulgaris on the eastern face. Thus, the abundance of dwarf juniper showed a positive correlation with the herbaceous components (Table 3). When juniper becomes abundant, both species richness and the diversity index increase. The abundance, closed canopies, and relative height of junipers, together with the northern orientation, imply an acute microclimate where shaded patches are dominant. The establishment of viable conifer propagules, even A. alba, could be difficult under these conditions. Moreover, this community is not livestock controlled because juniper bushes are highly impenetrable and not very palatable, and appear to be browsed only when other palatable species are absent (Day et al. 2003).

The southern face supports the main invasion of $P$. mugo. This is clearly related to the propagule pressure from the plantation established inside the pasture area and the relatively short distances attained by the seeds of this species. C. vulgaris may have played the most important nurse plant role for this species because $52 \%$ of invaders are currently surrounded by this shrub (Fig. 3). The scarcity of dwarf shrubs and the higher abundance of herbaceous components (Table 2) together with the warmer climate of the southern exposures could also explain the almost complete absence of A. alba colonizers on the southern slope. This species is known to be sensitive to aridity and, more concretely, to summer drought (Rolland et al. 1999).

In this paper we talk about conifer invasion "sensu lato," but we want to clarify the distinction between the process of "invasion" applied to P. sylvestris and P. mugo and the process of "spreading" applied to A. alba. That is, we take a biogeographical approach to describing an ecological phenomenon. In fact, the processes that determine species establishment, distribution, and abundance are similar for both indigenous and nonindigenous species (Davis et al. 2001). However, it is important to distinguish these terms to avoid controversies about invasion definitions and management 
decisions (e.g., Binggeli 1994; Colautti and MacIsaac 2004; Pysek et al. 2004).

\section{IMPLICATIONS}

The propagation of invading species in Montseny Natural Park coincides with park regulations that have encouraged the decline of traditional management (seasonal grazing and occasional burning) in the subalpine ecosystems. However, authorities may need to reconsider this position to avoid the transformation of heathland pastures. Nevertheless, natural factors that are much more difficult to control, such as the higher mean temperatures recorded since the 1940s, may have also facilitated the invading process.

Finally, some management considerations have emerged from this work. Taking into consideration the risk of losing a very rare ecosystem, such as the subalpine heathlands at the latitude of the Montseny mountain range, land managers must consider the option of removing conifer plantations or at least controlling their expansion (Etienne 2001). A conservation dilemma arises in the case of $A$. alba when the former heathland and the potential fir forest scenarios are put into balance. Firs are spreading only on a particular slope from a local population located on its meridional border, and A. alba is a species in regression in Europe. Considering this, the expansion of firs population should be tolerated even to the possible detriment of part of the heathland.

\section{ACKNOWLEDGMENTS}

We would like to thank Maria Jose Broncano, Salvador Català, Feliu López, and Roser Maneja for their collaboration. Research was funded in part by the Spanish Government (REN2002-03827) and Diputació de Barcelona (Natural Parks Service).

\section{LITERATURE CITED}

Barbéro, M., R. Loisel, P. Quézel, D. M. Richardson, and F. Romane. 1998. Pines of the Mediterranean Basin. In: D. M. Richardson [ED.]. Ecology and biogeography of Pinus. Cambridge, United Kingdom: Cambridge University Press. p. 153-170.

Bartolomé, J., J. Franch, and J. Plaixats. 1998. Diet selection by sheep and goats on Mediterranean heath-woodland range. Journal of Range Management 51:383-391.

Bartolomé, J., J. Plaixats, R. Fanlo, and M. Boada. 2004. Conservation of isolated Atlantic heathlands in the Mediterranean region: effects of land-use changes in he Montseny Biosphere Reserve (Spain). Biological Conservation 122(1):81-88.

BeRT, G. D. 1993. Impact of ecological factors, climate stresses, and pollution on growth and health of silver fir (Abies alba Mill.) in the Jura mountains: an ecological and dendrochronological study. Acta Oecologica 14:229246.

BingGeLI, P. 1994. Misuse of terminology and anthropomorphic concepts in the description of introduced species. Bulletin of the British Ecological Society 25:10-23.

BoAdA, M. 2001. Manifestacions del canvi ambiental global al Montseny [dissertation]. Barcelona, Spain: Universitat Autònoma de Barcelona. 430 p.

BoLòs, 0. 1983. La vegetació del Montseny. Barcelona, Spain: Diputació de Barcelona, Servei de Parcs Naturals. 170 p.
Bradshaw, R., and G. Hannon. 1992. Climatic change, human influence and disturbance regime in the control of vegetation dynamics within Fiby Forest, Sweden. Journal of Ecology 80(4):625-632.

BubB, K. A., And J. T. Croton. 2002. Effects on catchment water balance from the management of Pinus plantations on the coastal lowlands of south-east Queensland, Australia. Hydrological Processes 16(1):105-117.

Bustamante, R. 0., and J. A. Simonetti. 2005. Is Pinus radiata invading the native vegetation in Central Chile? Demographic responses in a fragmented forest. Biological Invasions 7:243-249.

Camarero, J. J., E. Martín, A. Padró, and E. Gil. 2002. Aproximación dendroecológica al decaimiento del abeto (Abies alba Mill.) en el Pirineo Aragonés. Montes 70:26-33.

Casper, B. B., and R. B. Jackson. 1997. Plant competition underground. Annual Review of Ecology and Systematics 28:545-570.

Colautti, R. I., and H. J. Maclsaac. 2004. A neutral terminology to define "invasive" species. Diversity and Distributions 10:135-141.

Davis, M. A., K. Thompson, and J. P. Grime. 2001. Charles S. Elton and the dissociation of invasion ecology from the rest of ecology. Diversity and Distributions 7:97-102.

Day, J., N. Nigel Symes, and P. Robertson. 2003. The scrub management handbook: guidance on the management of scrub on nature conservation sites. Wetherby, United Kingdom: The Forum for the Application of Conservation Techniques-English Nature. $45 \mathrm{p}$.

DıACI, J. 2002. Regeneration dynamics in a Norway spruce plantation on a silver fir-beech forest site in the Slovenian Alps. Forest Ecology and Management 161:27-38.

Dodson, J. R., And R. H. W. Bradshaw. 1987. A history of vegetation and fire, 6,600 B.P. to present, County Sligo, Western Ireland. Boreas 16(2):113-124.

Drezner, T. D., And C. M. Garrity. 2003. Saguaro distribution under nurse plants in Arizona's Sonoran Desert: directionals and microclimate influences. Professional Geographer 55(4):505-512.

Etienne, M. 2001. Pine trees-invaders or forerunners in Mediterranean-type ecosystems: a controversial point of view. Journal of Mediterranean Ecology 2(3-4):221-231.

Gómez Aparicio, L., R. Zamora, J. M. Gómez, J. A. Hódar, J. Castro, and E. Baraza. 2004. Applying plant facilitation to forest restoration: a meta-analysis of the use of shrubs as nurse plants. Ecological Applications 14(4):1128-1138.

Groves, R. H., and F. Di CAstri [eds.]. 1991. Biogeography of Mediterranean invasions. Cambridge, United Kingdom: Cambridge University Press. $501 \mathrm{p}$.

Higins, S. I., AND D. M. Richardson. 1998. Pine invasions in the southern hemisphere: modelling interactions between organism, environment and disturbance. Plant Ecology 135:79-93.

Hunter, G. G., AND M. H. Douglas. 1984. Spread of exotic conifers on South Island Rangelands. New Zealand Journal of Forestry 29:78-96.

Keeley, J. E., and P. H. Zedler. 1998. Evolution of life histories in Pinus. In: D. M. Richardson [ED.]. Ecology and biogeography of Pinus. Cambridge, United Kingdom: Cambridge University Press. p. 219-250.

Kienast, F., J. Fritschib, M. Bisseggera, and W. Abderhaldenc. 1999. Modeling successional patterns of high-elevation forests under changing herbivore pressure: responses at the landscape level. Forest Ecology and Management 120:35-46.

KILGORE, J. S., AND F. W. TeLEWSKI. 2004. Reforesting the jack pine barrens: a long-term common garden experiment. Forest Ecology and Management 189(1-3):171-187.

KUITERS, A. T. 2002. Hoofed animals in nature areas: theory and practice versus research. Vakblad Natuurbeheer 41:21-23.

Leban, J. M., F. Houllier, G. Pignard, and L. Saint-André. 1998. Assessment of longterm changes in timber quality: combining national forest inventory data and growth and wood quality models. In: T. Karjalinen, H. Spiecker, and O. Laroussine [EDS.]. Causes and consequences of accelerating tree growth in Europe. Nancy, France: European Forest Institute. $286 \mathrm{p}$.

LLoBet, S. 1947. El medi i la vida al Montseny. Barcelona, Spain: Consejo Superior de Investigaciones Científicas. $486 \mathrm{p}$.

Lodge, D. M. 1993. Biological invasions: lessons for ecology. Trends in Ecology and Evolution 8:133-137.

Mast, J. N., T. T. Veblen, and M. E. Hodgson. 1997. Tree invasion within a pine/ grassland ecotone: an approach with historic aerial photography and GIS modeling. Forest Ecology and Management 93(3):181-194. 
Palmer, S. C. F., and A. M. Truscot. 2003. Browsing by deer on naturally regenerating Scots pine (Pinus sylvestris $\mathrm{L}$.) and its effects on sapling growth. Forest Ecology and Management 182:31-47.

Peñuelas, J., and M. Boada. 2003. A global change-induced biome shift in the Montseny mountains (NE-Spain). Global Change Biology 9:131-140.

Pimentel, D. [ed.]. 2002. Biological invasions: economic and environmental costs of alien plant, animal and microbe species. Boca Raton, FL, USA: CRC Press. $392 p$.

Pysek, P., D. M. Richardson, M. Rejmanek, G. L. Webster, M. Williamson, and J. KIRSChner. 2004. Alien plants in checklists and floras: towards better communication between taxonomists and ecologists. Taxon 53:131-143.

Richardson, D. M. 1998. Forestry trees as invasive aliens. Conservation Biology 12(1):18-26.

Richardson, D. M., and W. J. Bond. 1991. Determinants of plants distribution: evidences from pine invasions. American Naturalist 137:639-668.

Richardson, D. M., and S. I. Higins. 1998. Pines as invaders in the southern hemisphere. In: D. M. Richardson [ED.]. Ecology and biogeography of Pinus. Cambridge, United Kingdom: Cambridge University Press. p. 450-473.

Richardson, D. M., And M. Rejmanek. 2004. Invasive conifers: aglobal survey and predictive framework. Diversity and Distributions 10:321-331.

Richardson, D. M., P. A. Williams, and R. J. Hobbs. 1994. Pine invasions in the Southern Hemisphere: determinants of spread and invadability. Journal of Biogeography 21:511-527.

RodweLL, J. S. [ED.]. 1991. British plant communities. Volume 2. Mires and heaths. Cambridge, United Kingdom: Cambridge University Press. 638 p.

Rolland, C., R. Michalet, C. Desplanque, A. Petetin, and S. Aimé. 1999. Ecological requirements of Abies alba in the French Alps derived from dendro-ecological analysis. Journal of Vegetation Science 10:297-306.

Rolland, C., V. Petitcolas, and R. Michalet. 1998. Changes in radial tree growth for Picea abies, Larix decidua, Pinus cembra and Pinus uncinata near the alpine timberline since 1750. Trees 13:40-53.
Rouget, M., D. M. Richardson, S. Lavorel, J. Vayreda, C. Gracia, and S. J. Milton. 2001. Determinants of distribution of six Pinus species in Catalonia, Spain. Journal of Vegetation Science 12(4):491-502.

Rousset, O., AND J. LEPART. 1999. Shrub facilitation of Quercus humilis regeneration in succession on calcareous grasslands. Journal of Vegetation Science 10:493-502.

RutTer, A. J. 1967. Studies of the water relations of Pinus sylvestris in plantation conditions. V. Responses to variation in soil water conditions. Journal of Applied Ecology 4(1):73-81.

Senn, J., And W. Suter. 2003. Ungulate browsing on silver fir (Abies alba) in the Swiss Alps: beliefs in search of supporting data. Forest Ecology and Management 181:151-164.

TyndalL, R. W. 1992. Historical considerations on conifer expansion in Maryland serpentine "barrens." Castanea 57(2):123-131.

Van Auken, O. W., And J. K. Bush. 1990. Importance of grass density and time of planting on Prosopis glandulosa seedling growth. Southwestern Naturalist 35:411-415.

Villar, L., A. M. Romo, and M. T. Perdigó. 1993. The beechwoods of the central Prepyrenees (Spain): a preliminary survey for conservation. Biological Conservation 66(2):85-93.

Waldrop, T. A., D. L. White, and S. M. Jones. 1992. Fire regimes for pine-grassland communities in the south-eastern United States. Forest Ecology and Management 47(1-4):195-210.

WiLliams, B. 2003. A comparison of heathland management practices, approaches and mechanisms in the U.K. and the Netherlands. London, United Kingdom: National Trust, Arkell Fellowship. 90 p.

Willis, K. J., K. D. Bennet, And H. J. B. BiRKs. 1998. The late Quaternary dynamics of pines in Europe. In: D. M. Richardson [ED.]. Ecology and biogeography of Pinus. Cambridge, United Kingdom: Cambridge University Press. p. 107-121.

Wolf, J. J., S. W. Beatty, And G. Carey. 2003. Invasion by sweet clover (Melilotus) in Montane grasslands, Rocky Mountain Natural Park. Annals of the Association of American Geographers 93(3):531-543. 